6. Мельник О.В., Чала О.В. Про деякі аспекти психології потерпілого під час кримінального провадження. Вісник Кримінологічної асоичіаиії України. 2013. № 4. С. 226-234.

7. Новак Р.В. Кримінальне провадження на підставі угод в Україні : дис. ... канд. юрид. наук : 12.00.09. Харків. 2015.214 с.

8. Таус М.М. Згода потерпілого на укладення угоди про визнання винуватості: окремі аспекти. Науковий вісник Дніпропетровського державного університету внутрішніх справ. 2020. № 1 (104). С. 300-305.

9. Твердохліб М.Г. Проблема законодавчого вдосконалення кримінального провадження на підставі угод. Порівняльно-аналітичне право. 2016. № 1. С. 358-361.

10. Тітко І.А. Нормативне забезпечення та практика реалізації приватного інтересу в кримінальному процесі України : дис. ... докт. юрид. наук : 12.00.09. Харків, 2016. 484 с.

11. Трекке А.С. Кримінальне провадження на підставі угоди про визнання винуватості : дис. ... канд. юрид. наук : 12.00.09. Ірпінь, 2018. 247c.

12. Холодило П. В. Кримінальне провадження на підставі угод про визнання винуватості : дис. ... канд. юрид. наук : 12.00.09. Київ, 2017. 296 с.

\title{
References:
}

1. Hloviuk I.V. (2017). Ukladennia uhod pro vyznannia vynuvatosti: okremi pytannia u konteksti onovlennia zakonodavstva [Conclusion of plea agreements: some issues in the context of updating the law]. Teoriia ta praktyka protydii zlochynnosti u suchasnykh umovakh: Mizhnar. nauk.-prakt. konf. (10 lystopada 2017 roku). Lviv: Lvivskyi derzhavnyi universytet vnutrishnikh sprav. S. 40-42.

2. Dobrovolska O.H. (2013) Problemy instytutu kryminalnoho provadzhennia na pidstavi uhod [Problem of the criminal proceedings on the basis of agreements]. Pravo i suspilstvo. № 5. S. 150-154.

3. Krasnopolska L.D. (2015) Instytut uhod pro vyznannia vyny v kryminalnomu provadzhenni Ukrainy [Legal rule ofinnocence in criminal production of Ukraine]. Ekonomika i pravo. Ser. 18. Vyp. 28. S. 167-175.

4. Lototskyi M.V.(2013) Uhoda pro vyznannia vynuvatosti: protsesualnyi poriadok ukladennia. Aktualni problemy vdoskonalennia chynnoho zakonodavstva Ukrainy [Confession of guilt agreement: procedural order of concluding]. Vyp. 31. S. 288-298.

5. Marchak V. (2013) Deiaki psykholohichni osoblyvosti uchasti poterpiloho v sudovomu rozghliadi [Some psychological characteristics of the victim's participation in the trial]. Visnyk Lvivskoho universytetu. Ser.: Yurydychna. Vyp. 57. S. 352-360.

6. Melnyk O.V., Chala O.V. (2013) Pro deiaki aspekty psykholohii poterpiloho pid chas kryminalnoho provadzhennia [About some aspects of the victim’s psychology during criminal proceedings]. Visnyk Kryminolohichnoi asotsiatsii Ukrainy. № 4. S. $226-234$.

7. Novak R.V. (2015) Kryminalne provadzhennia na pidstavi uhod v Ukraini [Criminal Proceedings on the Basis of Agreements in Ukraine]. Dys. ... kand. yuryd. nauk: 12.00.09. Kharkiv. 214 s.

8. Taus M.M. (2020) Zghoda poterpiloho na ukladennia uhody pro vyznannia vynuvatosti: okremi aspekty [Victim's consent to conclude a plea agreement as a tool to widen the scope of the institution of the agreement in criminal proceedings: certain aspects]. Naukovyi visnyk Dnipropetrovskoho derzhavnoho universytetu vnutrishnikh sprav. № 1 (104). S. 300-305.

9. Tverdokhlib M.H. (2016) Problema zakonodavchoho vdoskonalennia kryminalnoho provadzhennia na pidstavi uhod [The problem of legislative improvement of criminal proceedings on the basis of agreements]. Porivnialno-analitychne pravo. № 1. S. 358-361.

10. Titko I.A. (2016) Normatyvne zabezpechennia ta praktyka realizatsii pryvatnoho interesu v kryminalnomu protsesi Ukrainy [The regulatory support and practice of private interest realization in the criminal procedure of Ukraine]. Dys. ... d-ra yuryd. nauk: 12.00.09. Kharkiv. $484 \mathrm{~s}$.

11. Trekke A.S. (2018) Kryminalne provadzhennia na pidstavi uhody pro vyznannia vynuvatosti [Criminal proceedings on the basis of an agreement on the recognition of guilt]. Dys. ... kand. yuryd. nauk : 12.00.09. Irpin. $247 \mathrm{~s}$.

12. Kholodylo P.V. (2017) Kryminalne provadzhennia na pidstavi uhod pro vyznannia vynuvatosti [Criminal proceedings based on a guilty plea agreement]. Dys. ... kand. yuryd. nauk: 12.00.09. Kyiv. 296 s.

\section{DOI https://doi.org/10.51647/kelm.2020.4.1.20}

\section{МОВНИЙ СВІТ ПОЕТИЧНОГО ІДІОСТИЛЮ ІВАНА ПЕРЕПЕЛЯКА}

\author{
Вікторія Горенко \\ аспірантка кафедри української мови і літератури \\ Харківського начіонального педагогічного університету імені Г.С. Сковороди (Харків, Украӥна) \\ ORCID ID: 0000-0003-2697-2214
}

\begin{abstract}
Анотація. У статті втілено задум дослідити художньо-творчий потенціал мовної особистості Івана Перепеляка, що сприймається у різноманітному накопиченні ідей, образів, ситуативних сцен, емоцій тощо. Аналізуючи ідіостиль художника слова, варто не забувати єдність і цілісність письменницької концепції на тлі художньо-семантичної тканини творчості, враховувати органічну внутрішню взаємопов'язаність і взаємозалежність іiі елементів. У поезіях I. Перепеляка важливу функціональну роль відіграють художні тропи. Епітизація, метафоричність найчастіше пов'язані з асоціаціями у свідомості ліричного героя, і це зіставлення породжує метафору, метонімію, синекдоху, символ, порівняння, художній паралелізм тощо.
\end{abstract}

Ключові слова: ідіостиль, естетизми, вербалізація, концепт, епітизація, метафоричність, асоціативні домінанти. 


\title{
THE LANGUAGE WORLD OF IVAN PEREPELYAK'S POETIC IDIOSTYLE
}

\author{
Viktoriia Horenko \\ Postgraduate Student at the Department of Ukrainian Language and Literature \\ H.S. Skovoroda Kharkiv National Pedagogical University (Kharkiv, Ukraine) \\ ORCID ID: 0000-0003-2697-2214
}

\begin{abstract}
The article embodies the idea to explore the artistic and creative potential of the linguistic personality of Ivan Perepelyak, which is perceived in the diverse accumulation of ideas, images, situational scenes, emotions and more. Analyzing the idiosyncrasy of the artist's word, we should not forget the unity and integrity of the literary concept, against the background of the artistic and semantic fabric of creativity, take into account the organic internal interconnectedness and interdependence of its elements. Artistic paths play an important functional role in I. Perepelyak's poems. Epitization, metaphoricity are most often associated with associations in the mind of the lyrical hero, and this comparison gives rise to metaphor, metonymy, synecdoche, symbol, comparison, artistic parallelism, and so on.
\end{abstract}

Key words: idiostyle, aestheticisms, verbalization, concept, epitization, metaphoricity, associative dominants.

\section{ŚWIAT JĘZYKOWY IDIOSTYLU POETYCKIEGO IWANA PEREPELAKA}

\author{
Viktoriia Horenko \\ aspirantka Wydziału Języka i Literatury Ukraińskiej \\ Charkowskiego Narodowego Uniwersytetu Pedagogicznego im. H.S. Skoworody (Charków, Ukraina) \\ ORCID ID: 0000-0003-2697-2214
}

\begin{abstract}
Adnotacja. Artykuł ucieleśnia plan zbadania artystycznego i twórczego potencjału osobowości językowej Iwana Perepelaka, co jest postrzegany w szerokim gromadzeniu pomysłów, obrazów, scen sytuacyjnych, emocji i tym podobnych. Analizując idiostyl artysty słowa artystycznego, należy pamiętać o jedności i integralności koncepcji pisarskiej, na tle artystycznej i semantycznej tkaniny kreatywności, biorąc pod uwagę organiczną wewnętrzną wzajemną zależność i współzależność jej elementów. W poezji I. Perepelaka ważną rolę funkcjonalną odgrywają tropy artystyczne. Użycie epitetów, metaforyczność są najczęściej związane ze skojarzeniami w umyśle bohatera lirycznego, a to zestawienie rodzi metaforę, metonimię, synekdochę, symbol, porównanie, paralelizm artystyczny i tym podobne.
\end{abstract}

Słowa kluczowe: idiostyl, estetyzmy, werbalizacja, koncept, użycie epitetów, metaforyczność, dominanty asocjacyjne.

Вступ. Серед цінностей мовного ідіостилю Івана Перепеляка в діахронічній площині ментального світобачення автора особливо вирізняється краса, прекрасне, естетичне. У прекрасному втілюються природні соціальні особливості предметів і явищ, які співіснують із практикою людства, естетично освоюючи світ і реально відчуваючи прекрасне як цінність життя, створюють відповідну систему особистих знань про художньо вартісні об’єкти, предмети та явища, що здебільшого були частиною природи, довкілля. Автор тяжіє до зоровослухових аналогій у створенні метафоричного світу, до персоніфікацій, які репрезентуються у багатьох пейзажних замальовках. Персоніфікація у мовосвіті поета яскраво оформлює естетичне ставлення автора до природи, ілюструє світовідчуття особистості шляхом ідеалізації природних явищ і станів. Так звані «перепелякізми» вдало вербалізовані у різних морфологічних формах: іменниках, прикметниках, дієсловах, прислівниках.

Мета роботи - дослідити особливості поетичного ідіостилю Івана Перепеляка та його лексичну структуру. Досягнення мети передбачає виконання таких завдань: 1) виявити види художніх засобів, якими оперує поет у своїх творах; 2) з'ясувати поширеність їх в аналізованих текстах; 3) дослідити лексичний простір поетичного текстотворення.

Основні методи дослідження - метод вибірки фактичного матеріалу, спостереження за мовним матеріалом, описовий метод із прийомами інтерпретації, лінгвостилістичний аналіз, аналітико-синтетична обробка матеріалу.

Основна частина. Поетичний ідіостиль поета Перепеляка характеризується відтворенням естетичності довкілля й естетизацією буття героїв і мовною об'єктивацією цих глибинних концептуально-смислових кодів. Маємо на увазі лексичну структуру будь-якого поетичного полотна майстра, що уміщує у своєму семантичному аспекті майже всі сфери естетичного захоплення у власному мовному світі: ландшафтні краєвиди, рослинний світ (квіти), небо і небесні реалії, кольори, красу людини (зовнішню і внутрішню), позитивні відчуття, емоції, стосунки тощо. Доречно зазначити, що такі лінгвістичні знаки, які актуалізують ідею краси, художності, естетичності, можна визначити як слова-естетизми. Як відомо, до продуктивних естетизмів мовного світу поета слід віднести назви квітів, небесних світил лексико-семантичних груп (звірів, тварин, птахів): Згасало мовчки полум'я жасмину, / Як стрів тебе, задумливу й сумну. / Ховаючи у сериі таїну, / 3 твоїх очей скотилася сльозина. / Я зрозумів тебе. У ту хвилину / В свою ти поверталась далину. / Ти заплатила золоту ціну / За ту любов $і$ за мою провину... / В ошуканій душі холонув жар. / I, напинаючи вітрила хмар, / У човні серпня відпливало літо. / Стояла ти у тишині жалю. / Я запитав: - Як зберегти «люблю»? - / I не діждався я твого одвіту (Перепеляк, 2013: 93); Над хатою,над вербами старими / Пливе тривожно сине хмаровиння. / Вже перші засвітилися краплини, / Ще мить - $і$ хлюпне дощопад нестримно. / В чагарниках, у тиші насторожені / Принишкли квіти,щяоб побачить диво ... / Ген у грозу біжить дівча 
вродливе, / Комусь шука на рану подорожник... / Ну а комусь - приховує цикуту .../ Ті милі чари, як пелюстки рути, / Мов злива, ше на землю спрагло впала. / Душа ж тоді - у мороиі! - світала... / А блискавка майнула i пропала, / І хтось не встиг їі красу збагнути!.. (Перепеляк, 2013: 302).

Відрадно, що автор так легко запрошує у свій світ за допомогою важливих елементів зовнішньої естетизації довкілля у вигляді квітів і квітучих рослин - перцептивних ідентифікаторів краси насамперед природної, а не штучної. Як ми вже відзначали, квіти є важливим предметно-чуттєвим фактором творення естетичної картини світу українців, тому є певною інтерпретацією для поетичної мови, а також для інших сфер інтелектуально-мистецької діяльності (живопису, малярства, образотворчого мистецтва, вишивки, писанкарства тощо). Майже про всі різновиди квітів українці створили безліч легенд і переказів, неперевершених поезій i пісень, а тому центральним мотивом, що формує найдавніший зміст архетипу «квітка», є ототожнення iii 3 атрибутом Світового дерева. Цікавим із цього приводу є судження О. Маленко: «Із часом цей мотив було втрачено, натомість актуалізована естетична ознака квітів, що надалі відбилося у численних символах, порівняннях, зіставленнях, метафорах, різнорівневих словесних образах, продукованих художньою практикою кожної з культур. Отже, маємо реалізацію художньо-естетичної програми архетип - міф - символ (концепт) - образ» (Маленко, 2010: 151).

Будучи палким поціновувачем і прихильником квітів, Іван Перепеляк художньо «вплітає» у свій ідіостиль мовні транслятори відповідного концепту, якими є представлена палітра лексико-семантичних домінантів і конституентів-естетизмів: чебрець, сон-трава, ряст, папороть, жоржини, калинові мережива, матіола, любисток, жасмин, м'ята, ромашки, орхідеї, троянда, первоцвіт, осінній пізньоцвіт, гортензія, подорожник, рута: Поглянь, троянди пломінь загаса, / I день холоне у твоїи савані. / А далі? Щастя поведе в оману.../ Кому ж очей залишиться краса? (Перепеляк, 2013: 80); Здригнулось на подвір ’̈ деревце, / Як соки пробудилися рухомі. / Стежина в полі-досі невідома - / Дихнула запахущчим чебрецем (Перепеляк, 2013: 266); Калинові мережива щзодень / Гарнішають і тягнуться з затіння. / Час додає душі нових пісень, / Буйніших, як у чагарях извітіння (Перепеляк, 2013: 177); Моя утіхо! Рученьки слабі / В твоїй негоді шее вірніш изілую; Твій первоцвіт од лиха збережу я, / На посміх не віддам тебе юрбі (Перепеляк, 2013: 224); В розкриллі вишень - днина молода / Чеканням первоцвіту спалахнула. / Медами хмільно трави опахнули, / I відступила холодів біда... (Перепеляк, 2013: 256); Ще й місяць не устигне заясниться, / Торкнути сріблом повноводу гать. / А вже ромашки білі задзвенять, / I до світанку знов очам не спиться (Перепеляк, 2013: 257).

Світ людини та світ природи співвідноситься у поезіях до певної гармонізації існування усього живого в довкіллі. На переконання I. Перепеляка, чуттєва сфера кохання актуалізує опозиційні почуття - радість і сум (поетична збірка «Моєї радості печаль»). Відповідно це вербалізується у мовному світі поетичного ідіостилю митця певним протиставленням асоціативно-смислових і лексичних компонентів синтаксичного паралелізму: цвітіння квітки - кохання, радість, щастя, хвилювання; зів'яла квітка - нещастя, зрада в коханні, сум, сльози, тривога. Тому так ностальгічно звучать рядки: Моя любове, чому ти в журбі, /Що серие пломеніюче нудьгує? / Чи мало в світі хтось тебе шанує, / Чи проза буднів набрида тобі? / Моя утіхо! Рученьки слабі / В твоій негоді ще вірніш цілую. / Твій первоцвіт од лиха збережу я, / На посміх не віддам тебе юрбі. / Моє ти щзастя! Бачу наяву. / Кричу у світ розбурханий: - Живу! - / Уже й померти буде гріх з тобою. / Якщо тебе щуе хтось не відшукав, / 3 такими передчасно не лукав, / Не обійди нікого стороною! (Перепеляк, 1997: 65). Зустрічаємо риси оксиморону, аналізуючи тло поезії «І тьохне серце радістю сумне...»: 3 одним ти спиш, а любиш ти мене... / I отруївя я твоїм пороком. / Від того я $і$ ніжний, $і$ жорстокий, / Хоч ревність вже ось-ось наздожене... / I хтось мене, можливо, прокляне, / Та втрапив я в любовну замороку - / Вночі діждусь красуню синьооку, / I тьохне серие радістю сумне... / Я помолюсь на богорівну вроду. / I підемо, куди зове Природа, / Яку ніхто не сміє обдурить. / В своїй любові я лишусь відвертим, / Ступлю, по серие в чорній круговерті, / Аби пірнуть у високосну мить!.. (Перепеляк, 2013: 235). До речі, ця «річ у собі» при їі спогляданні конкретизує почуття ліричного героя, постаючи певною «матерією відчувань» у їі хаотичних вільних, невпорядкованих формах (Кант, 1995: 56). І лише ідіосвіт художника слова, яким є Іван Михайлович Перепеляк, здатен організувати цю «матерію відчувань», упорядкувати чуттєве споглядання світу. Завершуючи квіткову символіку, варто зазначити, що вона характерна для української ментальності у призмі свого тлумачення, зміст якого формувався рівнем поетичного ідіостилю Івана Перепеляка як реципієнта-творця на фоні загальної картини світу. Цікавим є факт, зазначений О. Маленко: «Інколи один і той самий символ наповнювався різним змістом, основу якого також становили певні аналогії означуваного з означеним. Так, калина символізувала дівчину, життя, кохання; барвінок символізував парубочу вдачу, рута - нещасливе кохання (у деяких тлумаченнях - кров, життя), біла лілея (рожа) - невинність, цноту; василечок (волошка) парубочу красу тощо. Якщо звернутися до естетичного виміру словесно-образної діяльності українців, то ілюстративним видається реєстр народнопоетичних епітетів щодо конкретних предметів і понять як мовносвітоглядний факт художньої інтерпретації довкілля » (Маленко, 2010: 55).

Отже, у палітрі народно-поетичних символів квітка як концепт є носієм потужної естетичної рефлексії, закодованих смислів, уявлень, аналогій. Як гімн Життєвій красі яскраво звучать рядки поезії «Весільні рушники несе життя»: Скороминуща літніх днів яса: / На пруг лягає сонще невблаганно, / Засмучене «курли» прозоро тане / У синіх вересневих небесах. / Поглянь - троянди пломінь пригаса, / Немов лікує хтось криваву рану. / А далі? Щастя заведе в оману - / Кому ж очей залишиться краса? / Весільні рушники несе життя, / Щоб квіткою всміхнулося дитя, / Яке твою перейме силу й вроду. / Оглянься - перша зморшка на чолі!../ А відлетять у вирій журавлі - / Не жди тепла і ласки у Природи... (Перепеляк, 2013: 225). 
Здавна у слов'янській міфології символом краси називали небесні світила. За визначенням О. Потебні: «Немає нічого $<. .>>$ як порівняння людей, їхньої краси і відповідних душевних станів із сонцем, місяием, зорею» (Потебня, 2000: 24). Та й у відомій українській щедрівці «Ой сивая та і зозуленька» згадуються ці небесні світила як одна сім'я божественних істот, що мають силу впливати на долю інших людей: Ясен місяць - пан господар / Красне сонце - жінка його / Дрібні зірки - його діти / Щедрий вечір, добрий вечір / Добрим людям на здоров'я!. Таке порівняння знаходимо в іншому творі: В тій церковиі три вікония: / В першому вікониі ясне сонце. / В другому віконці - ясний місяченько, / В третім вікониі - ясні зіроньки. / Що зіроньки - то дітоньки, / Що ясне сонце - то господиня, / Що місяченько, то сам господар (Перепеляк, 2013: 424). Багато історичних джерел указують, називають усі об'єкти та явища, на які розповсюджувався культ світла й вогню, а вони мали здатність випромінювати світло, порівнюючись із обличчям красивої, гарної людини.

У поетичній мові Івана Перепеляка ми чітко помічаємо саме конкретно чуттєве уявлення, яке формує значення слова-символу у такій структурі: сонще - світло - тепло - краса. У поезії «Чи світ співає, чи душа...» він наголошує: Щоб знову сонцю порадіти... / А то ліниво в спеку літа / Із холодку не поспіша (Перепеляк, 2013: 173); «Я в поле на світанні поспішаю...»: Клечається земля барвистим ивітом / Мов наречена, у вінок одіта, / Вклонясться і сонцю, і весні (Перепеляк, 2013: 176); Скороминуща літепла яса -/ На пруг лягає сонце невблаганно. / Засмучене «курли» в озерах кане / Що ронять вересневі небеса (Перепеляк, 2013: 80). Поетичне полотно майстра виграє палітрою художніх тропів, що підсилюють задану персоніфікацію сонця засобами метафоризації: Сонце обрій здвигнуло / I вийило на кручі (Перепеляк, 2013: 135); Давно вже над тобою чорне сонще / А що на тому світі ти знайшов? (Перепеляк, 2013: 278); Знову покличуть плуги / Буде сонце в промінні (Перепеляк, 2013: 279); Хмарою кінських грив / Закривали / Чужсиниі / Моє сонце (Перепеляк, 2013: 341); I пахнуть сонцем знайдені слова (Перепеляк, 2013: 130); Сходить сонце на круту орбіту (Перепеляк, 2013: 137); Над світом сонце круто поверта (Перепеляк, 2013: 138); Древне сонце в сірім небі править (Перепеляк, 2013: 156); I вранішнє сонце на світанні було в головах (Перепеляк, 2013: 433); На пруг лягає сонце (Перепеляк, 2013: 441); Як моє Сонце вийшло на орбіту... А я до Сонця прихиляюся щоночі (Перепеляк: 442); I перед сонщем у душевнім храмі (Перепеляк, 2013: 449); Згоріли в сонці тіні голубі (Перепеляк, 2013: 465); За обрій сонце круто поверта (Перепеляк, 2013: 471); I напитися сонця вдосталь (Перепеляк, 2013: 472); Сонце холодне в небі» (Перепеляк, 2013: 485). Про захоплення яскравим світилом автор наголошує у рядках: «Онуком Сонця вважаю себе я здавна / I слово «сонце» мені близьке до слова слов'янин / Про Сонще мовлю я мов про живе створіння, / Воно людей пробуджує від сну / I укладає спати ... / Я - сонцепоклонник! / І Сонце для мене - як Бог! (Перепеляк, 1997: 56).

У поезіях митець використовує різні епітети (сонцесяйні персні): У світ хлюпнуло сонячне звучання (Перепеляк, 2013: 120); Будь сонячною! Як ідуть дощі .. / Шукаю сонячно-небесні очі (Перепеляк, 2013: 463). Художні тропи використовуються і в інших ставленнях ліричного героя до символу світла і тепла: $T u$ - моя неубита воля, / Передсмертний до сонщя крик!.. (Перепеляк, 2013: 126); Хвала весні і сонцю! Знов мені / Іти у нескінченній борозні (Перепеляк, 2013: 127); I славу Богу возвели. / I німб уподібнили сонцю (Перепеляк, 2013: 200); Знову зло я під сонием побачив - / Величезне, страшне для людини! (Перепеляк, 2013: 206); Марнотних днів відкрилася огуда, / Й нічого не змінилося під сонцем! (Перепеляк, 2013: 209); Якби ти був зі мною - день і ніч, / Я прихилила б сонечко до віч (Перепеляк, 2013: 227); Лише до сонця стане ближче Україна, / Я зачілую твої очі золоті (Перепеляк, 2013: 237); I сонцем повниться твоя світлиия... / Чим більше пізнаєш себе самого (Перепеляк, 2013: 296); Молилась сонцю - богу із богів, / Аж поки сонще не зайшло за обрій... / I обрів допікав смертельний гнів: / Переманити душу як? - питали обри... (Перепеляк, 2013: 335); Земля... мов наречена у вінок одіта / Вклонясться і сонцю і весні (Перепеляк, 2013: 122); А то -зажуриться до сліз, / Щоб знову сонцю порадіти (Перепеляк, 2013: 131); Вродливі молоді жінки / На сонці білять рушники (Перепеляк, 2013: 145); Ти посміхнешся сонячно, а промінь, бачу, зблід (Перепеляк, 2013: 146); Бігла довго за сонцем радість?/ Заблукала в борозні (Перепеляк, 2013: 160); Не встиг його пізнати алфавіт, / Як викрадає ніч сонцеписання (Перепеляк, 2013: 439); I перед сонцем у душевнім храмі / Спинюсь, подібний горе-жебраку (Перепеляк, 2013: 449); Як на вечірнім зимнім небокраї згоріли в сонці тіні голубі (Перепеляк, 2013: 465); Не зупинити сонячнулавину, I пристрасть відкриває нам вершину (Перепеляк, 1997: 48). Як ми вже зазначали вище, у міфопоетичній свідомості наших предків символом чоловічого роду ототожнювався місяць, а тому у деяких поетичних рядках Іван Перепеляк ототожнює його з особами чоловічої статі: батьком, молодим парубком-красенем, закоханим юнаком. Тому це небесне світило відтворюється художником слова у відповідних текстоситуаціях: Пасу я вірних коней над Сулою, / I мій підпасич - місяць-молодик (Перепеляк, 2013: 41); Срібен місяць у небі долі, / Що козаиьким вусом провис (Перепеляк, 2013: 126); Дарма! Із піснею про Байду, / Під місящем холодним до зорі! (Перепеляк, 2013: 58); Де місяць пада шаблею на воду, / І в небеса спинаються зірки (Перепеляк, 2013: 176); І місяць посивіє, / Не дочекавшись додому (Перепеляк, 2013: 545); У надвечір'я - особливі чари: / Проллється місяць - заблищить роса (Перепеляк, 2013: 562); Не зажурить місяць / Золоту брову (Перепеляк, 2013: 124); Наш світ білий появився від Бога / Червінь Сонще - /3 лиия - Божого, / Світлий місяць - / Із грудей його, / Білі зорі - / Із очей Божих, / Ясні зорі - з одеж його (Перепеляк, 1997: 65). На нашу думку, митець уміє встановлювати асоціативні кореляти між природними явищами та почуттями людини шляхом одухотворення й естетизації навколишнього світу природи, i це органічне поєднання поет відобразив у ще одному символічному образі зорі, який вербалізується у синонімічних означеннях: зірка блискуча, видна, гаряча, діамантова, золота, кришталева, мерехтлива, осяйна, перлиста, прозора, промениста, рубінова, срібляста, сяйна та ін. (СУМ, 1980: 149). Так, І. Перепеляк креативно конкретизує поетичне осмислення концепту зоря, зірка як символу 
рідної землі. Художньо-семантична сфера АВТОР - ЗОРЯ характеризується здебільшого рисами ліричності та інтимності, тому авторське споглядання на універсальний образ зорі слугує позначенням найвищої мети, пов'язується з чистими людськими почуттями (любові й вірності), спробою зіставити поняття зірки 3 молодою дівчиною. Рядки поетичних текстів майорять світосприйняттям Перепеляка через призму художніх засобів, алегоричності, персоніфікації, метафор: Пролилася зоря / Розиифрувавши / Закодовану тишу, / I підпалила / Чорної ночі хрест!.. (Перепеляк, 2013: 107); Коли зоря скривавиться за обрій, / А я круті завали перейду, (Перепеляк, 2013: 177); Небо в хмарі потонуло: / Не знайти зорі!... / Мороком вкривалось поле. / Зірку б хоч одну!... (Перепеляк, 2013: 276); Над хатою - осіння ватра зір, / І вічність зупинилася, як мить (Перепеляк, 2013: 273); Роздмухай спогад-полум'я іповернувиисьувчора, / Дерозписавсь зорею нанебесах душі! (Перепеляк, 2013: 201); Як зоря падуча пролетить, / Небо розтинаючи глибоке, - / Я до ранкузагадаю мить (Перепеляк, 2013: 385); Згасали в мороияі високі зорі (Перепеляк, 2013: 541); В останнім віражі зоря на небосхилі (Перепеляк, 2013: 135); Зоря ж заболить у небі-стане знов тепло і легко (Перепеляк, 2013: 152); В моєму ж небі не знайти ані зорі (Перепеляк, 2013: 445); Світаюча зоря не забавля, / Що синім світлом огортає небо (Перепеляк, 2013: 489). Художньо-образну універсалію зоря поет нерідко фіксує синонімічними парами: зірка, зірниця, зоряниця: Де місяиь пада шаблею на воду, / І в небеса спинаються зірки, (Перепеляк, 2013: 176); Там дівчата диво-чарівнииі / Защебечуть, наче ластівки. / І нікому в ніч таку не спиться-пахнуть матіолами зірки (Перепеляк, 2013: 265); Щоб зірка в небі зірку переймала (Перепеляк, 2013: 423); I дихали світлом дивно розквітлі зірки (Перепеляк, 2013: 433); Небо в хмарі потонуло:/Не знайти зорі!.. / Мороком вкривалось поле. / Зірку б хоч одну!.. (Перепеляк, 2013: 276); Тече на трави / Промінь зоряниці, / Що пережив лютневі холоди (Перепеляк, 2013: 386); Блукали очі в небі по зірках (Перепеляк, 2013: 394); Вечірній присмак зірку підійма (Перепеляк, 2013: 546); I до зірок сягають явори (Перепеляк, 2013: 120); Дослухається зірниця, / шчо шумлять дуби високі в тиші вечорів? (Перепеляк, 2013: 142); Шлях їй осяває зірка світова (Перепеляк, 2013: 144); В космосі тихо - звідки цей вітер? / У душу - колючі зірки (Перепеляк, 2013: 155); На виповнену медом сіножать / Голубозорі дивляться зірниці (Перепеляк, 2013: 406). Мовомислення автора відзначається харизмою щодо наявності авторських неологізмів: Коники нап 'ються / знов зорінь-води (Перепеляк, 2013: 124); Скреслим зорепадом хлюпа в сон-траву (Перепеляк, 2013: 124). Мовостиль Івана Перепеляка збагачується художньою епітизацією цих символічних номінацій: I кличе Доля в зорянім віниі! (Перепеляк, 1997: 41); Гарячий дух акацій і любистку / I поля світанкового теплінь / Пливуть над світом в зоряній колисці (Перепеляк, 2013: 274).

Митець органічно вербалізує універсалії сонце, місяц̧ь, зоря, підкреслюючи повноту та взаємозалежність цих народнопоетичних образів, що підкреслюють єдність трьох поколінь у традиційній українській сім’ї: Зәлянься сонцее, осіннє сонцее! / Старезний дід куняє на призьбі / Зглянься, місяцю, ясний місяцю! / Дай-но зігрітись під холодним теплом / Зорі, високі байдужі зорі / Подаруйте останню пригориу мрій (Перепеляк, 2013: 143); Ворожимо по Сонц̧ю і Зірках / Як завжди, ми ворожим проти ворога, / Від того й «ворожити», «ворожіння»... (Перепеляк, 2013: 344); Зглянься, Сонце, осіннє соние! / Старезний дід куняє на призьбі / Зглянься, місяцяю, ясний місяц̧ю! / Дай-но зігрітись під холодним теплом / Зорі, високі, байдужі зорі! / Подаруйте останню пригориу мрій (Перепеляк, 2013: 143). Певної символізації у свідомості українців зазнав «місяц̧ь», який ототожнювався з особою чоловічої статі, зокрема батьком, молодим парубком-красенем. Цитуємо думки Олени Маленко: «Асоціативними мотиваторами, закладеними в символічну модель місяць - парубок, є маскулінна ідентифікація місяця за родовою ознакою (в українській мові слово місяц̧ь чоловічого роду), наявність фази молодого місяця (місяць-молодик - молодий парубок, юнак, хлопець), а також чуттєва сфера, зокрема кохання (зустрічі закоханих вночі при світлі місяця, який уважався покровителем кохання). Естетичний (краса світила) й функціональний (здатність освітлювати) параметри місяця як природної реалії органічно синтезувалися у традиційному поетичному уособленні місяия 3 парубком - красивим, молодим, здатним до кохання» (Маленко, 2010: 159). Семантична кореляція слів місяць-батько, місяць-хлопецьь (парубок) відтворена в ідіостилі I. Перепеляка: $B$ нічнім степу я чую волі крик / Так недалеко можна й до розбою... / Пасу я вірних коней над Сулою / I мій підпасич - місяцьмолодик (Перепеляк, 2013: 172). Приваблює читача символічний образ зірки (зорі), до якого звертається поет і порівнює його з красою і вродою молодої дівчини. Цікавим є дослідження О. Маленко: Ой зійди, зійди зірничко весіння. / Ой вийди, вийди, дівчино сусідня; / Ой зійила зоря, все поле освітила, / Вийшла дівчина, серденько розвеселила (Маленко, 2010: 153); Зійила зірка з-під вечірка / Та впала додолу. / А хто мене, молодую, / Одведе додому? (Маленко, 2010: 161); Ой зійшли, зійшли/ Дві зіроньки ясні, / Ой вишли, вийшли / Дві дівоньки красні (Маленко, 2010: 319); За нашим городом / Три зірочки ясних. / Три зірочки ясних, / Три дівочки красних (Маленко, 2010: 322). Будучи уважним дослідником слов'янських легенд і міфів, Іван Михайлович також використовує цей символ краси у своїх поезіях: Не уступай нещастю, iдu навстріч сміливо / Сказав мудрець про Долю і на словах здригнувсь / Не піддавайсь жалобі, аби не згаснув пломінь / Допоки в передвісті витьохкує зоря (Перепеляк, 2013: 12); У відчаї зоря сплакне на небесі / Коли зберуться нечестивиі всі (Перепеляк, 2013: 147). Здебільшого семантично прозорим є мотив праведності, святості у контекстній реалізації смислових і асоціативних домінант символу зірка. Тому художник слова органічно зближує його з іншими конституентами поданої лексико-семантичної групи у форматі свого ідіостилю, називаючи небо, вітер, дощ, сніг, веселку тощо. Звернімо увагу: Тепла не жди! Січневі небеса / На стежку накликають веремію... / Твій образ за снігами даленіє, / Від того щзось пече... / I не згаса (Перепеляк, 2013: 95). Стихає вітру сонне колихання, / Принишкла тиша горнеться до віт. / Схиливиись на осінній живопліт, / У вікна задивилося смеркання (Перепеляк, 2013: 222). 
Висновки. Отже, досліджуючи мовосферу Івана Перепеляка, ми переконалися у його відповідності, підпорядкованості мовних засобів твору, що розкривають творчий задум засобами лексики (авторські лексеми - перепелякізми), художніх тропів (метафори, персоніфікації, епітетів, порівнянь, метонімії, гіперболи, антитези тощо), власних стилістичних фігур. Погодьмося, що мовно-поетичний ідіостиль поета характеризується наявністю особливих ментальних структур, а його мовна натура служить своєрідним способом суб'єктивного посередництва між текстом і світом і виражає авторську духовно-образну позицію у довкіллі та щодо всього світу.

\title{
Список використаних джерел:
}

1. Маленко О.О. Лінгво-естетична інтерпретація буття в українській поетичній мовотворчості (від фольклору до постмодерну) : монографія. Харків, 2010. 488 с.

2. Кант И. Избранное : в 3 т. Калининград, 1995-1998. Т. 2. 304 с.

3. Перепеляк I.M. Неопалима купина. Вірші, поеми. Харків, 1997. 161 с.

4. Перепеляк І.М. Поезії та поеми. Т. 1. Харків, 2013. 592 с.

5. Перепеляк І.М. Поезії та поеми. Т. 2. Харків, 2013. 632 с.

6. Перепеляк. І.М. Полтавські сонети. Харків, 2018. 328 с.

7. Потебня А.А. Символ и миф в народной культуре. Москва, 2000. 480 с.

8. Словник української мови. Київ, 1980. Т. 11. С. 330.

\section{References:}

1. Malenko O.O Linhvo-estetychna interpretatsiia buttia v ukrainskii poetychnii movotvorchosti (vid folkloru do postmodernu) [Linguo-aesthetic interpretation of life in Ukrainian poetic language creation (from folklore to postmodernism)]: Monograph. Kharkiv, 2010. 488 p.

2. Kant I. Yzbrannoe: V 3 t [Favorites: In 3 volumes]. Kaliningrad, 1995-1998. Vol. 2. 304 p.

3. Perepelyak I.M. Neopalyma kupyna [Incombustible blackberry]. Poems, poems. Kharkiv, 1997. 161 p.

4. Perepelyak I.M. Poezii ta poemy [Poetry and poems]. Vol. 1. Kharkiv, 2013. 592 p.

5. Perepelyak I.M. Poezii ta poemy [Poetry and poems]. Vol. 2. Kharkiv, 2013. 632 p.

6. Perepelyak I.M. Poltavski sonety [Poltava sonnets]. Kharkiv, 2018. 328 p.

7. Potebnya A.A. Simvol i mif v narodnoi kulture [Symbol and myth in folk culture]. Moscow, 2000. 480 p.

8. Slovnyk ukrainskoi movy [Dictionary of the Ukrainian language]. Kyiv, 1980. Vol. 11. P. 330.

DOI https://doi.org/10.51647/kelm.2020.4.1.21

\section{THE LIFE IN THE GREAT WORLD: THE WAY TO SUCCESS OF SAMUEL RICHARDSON'S HEROINE}

\author{
Nataliia Kaliberda \\ Lecturer at the Department of English for Non-Philological Specialities \\ Oles Honchar Dnipro National University (Dnipro, Ukraine) \\ ORCID ID: 0000-0002-9503-8006
}

\begin{abstract}
The article highlights the poetics of the texts written by Richardson as a continuation of the novel "Pamela, or Virtue Rewarded". It denotes the approaches to describing the shifts and the expansion of the possibilities of the epistolary form in the third and the fourth volumes of the book about Pamela. The concepts of the characters, the methods of creating the world of heroes, as well as the mechanism of the plot, are examined. Attention is focused on the ways of deploying of artistic space and time in the novels, the spatial and temporal markers as symbols. It is argued that while Volume I allows for mobility within the social structure for Pamela as long as she is virtuous, Volume II is simply about redirecting that power back in the domestic sphere of a socially controlled male ordered society. The fact that the postmarital parts of "Pamela" deal seriously with a broad range of social issues, centered on the corruption and reform of the aristocracy and the tension between sexuality and social stability, is also stressed.

Key words: world of heroes, plot, poetics of characters, artistic time and space, gender, theme of motherhood, novel of manners.
\end{abstract}

\section{ЖИТТЯ У ВИЩОМУ СВІТІ: ШЛЯХ ДО УСПІХУ ГЕРОЇНІ СЕМЮЕЛА РІЧАРДСОНА}

\author{
Наталія Каліберда \\ викладач кафедри англійської мови для нефілологічних спеціальностей \\ Дніпровського національного університету імені Олеся Гончара (Дніпро, Украӥна)
}

ORCID ID: 0000-0002-9503-8006

Анотація. Стаття висвітлює особливості поетики текстів, написаних Річардсоном як продовження роману «Памела, або Винагороджена доброчинність». Позначені підходи до опису зрушень і розширення можливостей 